\title{
Impact of Human Resource Management Practices on Behavioural Outcomes of Financial Institutions of Nepal
}

\author{
Gopal Man Pradhan, PhD \\ Associate Professor, Tribhuvan University \\ Visiting Faculty, Nesfield International College \\ Email: pradhangopalman@gmail.com
}

\begin{abstract}
This study is based on the impact of HRM practices on organizational performance in terms of behavioral outcomes of financial institutions of Nepal. The variables of HRM practices involve recruitment and selection, training and development, performance appraisal, career planning, compensation, employee participation, and job design whereas variable of behavioral outcomes involve motivation, cooperation, involvement and organizational citizenship. In this study, while analyzing the beta coefficient, it is found that job design sensitivity to organizational performance is high followed by employee participation and compensation system. But all other variables recruitment and selection training and development, and career planning have also positive impact on behaviour outcomes of organizational performance. However, recruitment and selection, training and development, and career planning have minimum impact on behaviour outcomes of organizational performance.
\end{abstract}

Keywords: HRM practices, motivation, cooperation, involvement, organizational citizenship, descriptive search

\section{Introduction}

The present era of business is the age of globalization where there is more scope of business having qualitative products and services; however along with scope of business the entrepreneurs have to face keen competition not only with national entrepreneurs but also with international business organizations. The emerging global competition where more focus have given on customer satisfaction, speed in work and flexibility in business have created challenges in all types of organizations in modern market economy. The competitive forces that managers face today will continue to confront in future demand of organizational excellence. The effort to achieve such excellence are through the fundamental elements of the human resource management that is focusing on learning, quality of work, team work and 
reengineering which are driven by the way organization get things done and how they treat their people.

Regarding the human resource management in Nepalese business organizations, very few researches have been made by linking the business strategy, human resource management and human resource outcome. Adhikari (2005) suggests that there have been no significant change at firm level HR policies and practices even after the changes in the economic and political priorities in the last decade Nepal is still at the initial stage of the development of human resource management. Human resource planning and practices are not in the priorities of Nepalese managers. There are several approaches given by the scholars in the field of human resource management and its relationship with performance. Guest (2002) prescribed three dominant approaches in defining the key way in which human resource management might enhance corporate and the strategic fit model. When it comes to developing nations like Nepal the role of human resource is visible only in those organizations, which either are knowledge organizations or are technology intensive organization.

\section{Statement of Problem}

The initial research on HR practices and organizational performance was, unsurprisingly greeted with much enthusiasm by academics and practitioners alike, and the figures appear impressive and authoritative (Richardson and Thompson, 1999). However, researchers (Huselid, 1995; Guest, 2005) in this area have recognized some of the limitations of the research approach to date and there has been an increasing body of criticism related to early work, which was almost, completely comprised of quantitative data analyzed statistically. The criticism in relation to the assessment of HR polices and practice relates to three areas: the reliability of the data; the lack of depth and breadth in the data; and the conceptual model within which the research was carried out.

In Nepal, some studies have been carried by making relation between human resource management practices and overall performance of the organization. Adhikari and Muller (2005) concluded that there are opportunities and challenges for implementation of western type human resource management to developing countries. Pant (1982) described that Nepalese managers emphasized on affective commitment as compare with components of commitment. Most of Nepalese entrepreneurs and managers are usually not convinced about the benefits of more investment in human resources. However, some corporate and even government institutions are started to realize the value of human research development for 
institutional benefit. Some Nepalese scholars and academicians have involved in research of this area but it is more to do.

\section{Research Questions}

The question in this study involves addressing the impact of HRM practices and behavioural outcomes of banking sector organizations. However, the following are the common questions of this study:

- What is the status of the HRM practices in Nepalese banking sector organizations?

- What is the effect of HRM practices on behaviour outcomes of banking sectors organizations?

- What is the effect of moderating variables on HRM practices behavioural outcomes of banking organization?

\section{Research Objective}

The main objective of this research work is to find out the impact of human resource management practice on behavioural outcomes of Nepalese banking sectors. This study also attempts to find out the relationship between human resource management practices and overall firm performance. This study attempts to achieve the following objectives.

- To find out the status of the HR practices in Nepalese banking sector organizations.

- To examine the effect of HR practices on behaviour outcomes of banking sectors organizations.

- To examine the effects of HR variables on HRM practices on organizational performance.

\section{Significance of the Study}

The innovation of new science and technology and implementation of that knowledge in business has contributed for repaid change in production, distribution and service sectors. The evolution of World Trade Organization has brought both opportunity and threat for Nepalese organizations. This study might give an insight on the relationship between HRM and performance in the context of least developed country like Nepal, and in service sector. The success of the business organization largely depends on the effectiveness and quality of the services that they provide to the customers. Keeping these views into consideration, this study is expected to be fruitful to explore the HRM Practices that exist in banking sector and their effects on 
the organization and employee performance. From a practical perspective, the findings of this study will be useful to top management, functional and HRM managers to design their HRM practices within a strategic condition at the micro or macro organizational level in order to improve future organizational performance.

\section{Limitations of the Study}

In this study the researcher is considered appropriate research methodologies to come up with reliable result. But, there may be some notable research limitations, which are mentioned as:

- The constituents of behaviour outcomes used under this study may not be equally applicable in all organizations having different background.

- This study is based on cross sectional data, which may not to show the time lag effects of the variables under study.

- The human resource practice variables used under this study may not represent to all the variables required for other organizations.

- This study is confined only to limited banking sector organization, so, the finding of this study may not represent all the institutions.

- All the information and data used in the study are collected from primary sources through survey method, therefore, the validity of the data depends upon the individual perception of the respondents.

\section{Theories of Linkage between HRM and Performance}

Guest (1997) argued that neither the strategic nor the descriptive model provide much insight into how HRM policy and practice translate into high performance. Researchers view that HRM as only part of the explanation for high performance and suggest that, when the various sub-systems including the HRM sub-systems are aligned and supporting to each other, superior performance is likely. The descriptive model gives more importance to the active role of employees but in negotiating order. In contrast, the normative approach has its roots in organizational psychology. The assumption is that appropriate HRM practices tap the motivation and commitment of employees. The key features of this approach are that HRM provides a coherent integration of these behavioural theories and they spell out the linkage between practices and performance. McDuffie (1995) provided a base for the linkage closely related to expectancy theory. Based on this base Guest (1997) developed a typology presenting the relationship between HR practices and organizational performance. Various empirical studies were made linking HR practices with HRM outcomes, individual outcomes, behavioral outcomes, 
performance outcomes and financial outcomes. In this study, researcher has maintained link between HRM practices with organizational performance in term of behavioral outcomes which involve motivation, cooperation, involvement and organizational citizenship.

\section{Framework of the Study}

HRM practices influence employee skills through the acquisition and development of a firm's human capital. Therefore, in anticipation of an estimation model that focuses on these dependent variables, the review of the empirical literature concentrates on prior work examining the influence of HRM practices on employee performance. In this study, it is tried to make link between the impacts of human resource management practices on organizational performance in term of behavioral outcomes. The elements of human resource management consisting of recruitment and selection, training and development, performance appraisal, career planning, compensation, employee participation, and job description have positive impact on employee performance in terms of behavioral outcomes which involves motivation, cooperation, involvement and organizational citizenship.

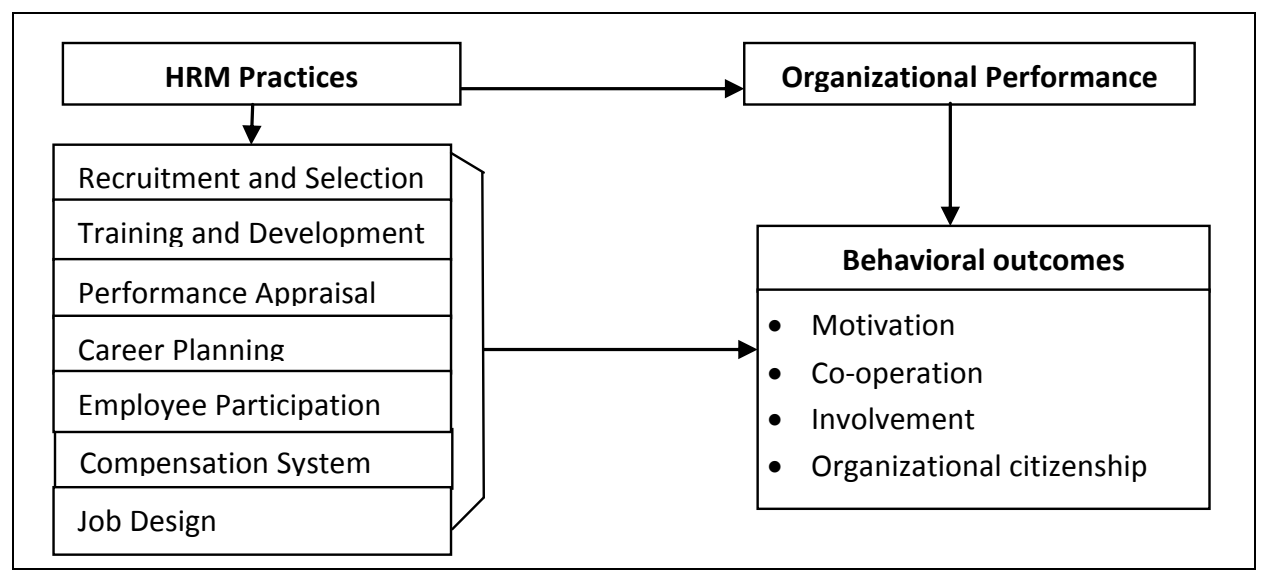

Figure 1. Research framework

\section{Nature of Research}

This study is based on primary data obtained by distributing questionnaires to selected respondents. Therefore, it is descriptive, co-relational, causal comparison type of research. In this research some selected human resource management practice variables have been taken into account for getting feedback from both managerial and assistant level employees of selected commercial banks. Besides, 
behavioral outcomes have been measured in terms of employees' motivation, cooperation, involvement and organizational citizenship of selected commercial banks. In this study it is tried to maintain co-relation and link among HRM practices variables and organizational performance in terms of behavioral outcomes.

\section{Research Design}

The research designed adopted in this study consists of descriptive, co-relational, and causal comparative research design to analysis the various issues are raised. The descriptive research design is used for the purpose of fact-finding, conceptualization, description, and operation searching for adequate information in the context of RHM practices and organizational performance in terms of behavioral outcomes in Nepal. This study has also adopted correlation research design to establish the relationship between HRM practices and organizational performance. The research design adopted in this is identical as the previous researches taken place, for example Guest, 2002. HR practices build job infrastructure that can provide maximum amount of information to employee, decentralize decision making, and motivate employees to attain organizational goals (McDuffie, 1995; Wright et al., 1997)

\section{Research Hypothesis}

The broad objectives of this study are to explore the relationship between the uses of human resource management practices and their impact on organizational performance in terms of behavioral outcomes. Its objective is also to compare the result obtained in the public and private sector banking institutions. On the basis of above objectives and relation, following hypotheses are explored:

Hypothesis 1: There is a positive and significant effect of greater use of human resource management practices on high level of employee motivation.

Hypothesis 2: There is a positive and significant effect of greater use of human resource management practices on employee cooperation.

Hypothesis 3: There is a positive and significant effect of greater use of human resource practices on employee job involvement.

Hypothesis 4: There is a positive and significant effect of greater use of human resource practices on employee organizational citizenship.

\section{Sources and Nature of Data}

For the purpose of fulfillment of the objectives of the research, necessary data and information was collected through primary sources i.e. questionnaire. Data used in this study were collected from fifteen banking institutions consisting of ten commercial banks. In this survey research, three categories of information namely 
Impact of Human Resource Management Practices on Behavioural Outcomes of Financial Institutions of Nepal : Pradhan $\mid$

detail information of respondents, human resource practice and organizational outcomes were collected. The questionnaire was developed from prior literature as used by Guest (2002). Basically, normative theory of maintaining link between human resource management practices and behaviour outcomes of organizational performance is taken into account in this research work.

\section{Population and Sample Size}

The instruments are administered by the researcher with the help of friend circle and recommendation from professionals. The researcher explained the purpose of the study and all aspects of the questionnaire to the respondents. The selected respondents are employees working in different levels consisting of managerial, officer and assistant level of both in head office and branch offices in different part of the country. They are made to understand that all information being provide would be treated with confidentially and for the purpose of research only. In this study, ten commercial banks are taken into account as samples to analyze. In total 455 questionnaire have been distributed and 405 (89.01\%) copies that are completely filled and returned are utilized for the purpose of the study.

\section{Measurement of HRM Practices and Behavioral Outcomes}

In the study HRM practices are measured by considering seven items consisting of recruitment and selection, training and development, performance appraisal, career planning, compensation system, employee participation and job design. It is based on the normative theory of HRM practices by Huselid and Rau (1997). The organizational performance is measured by considering behavioral outcomes in terms of employee motivation, employee cooperation, and employee involvement and employee organizational citizenship. It is based on the normative theory of HRM practices and organizational performance by Guest (2002).

\section{Effect of HR Practices on Behavioral Outcomes}

HR practices have been considered as important function of management in present business world. The major challenge for organizations in the future seems likely to be an ever more urgent search for competitive advantage. It is increasingly argued that the organization best able to meet this challenge will be those that can acquire and utilize valuable, scare and inimitable resources (Barney, 1991). Guest (2000) has argued that if we move towards a behavioral model, we might wish to link employee perception to their behaviour to individual or group level performance outcomes that affect unit performance and thus to company performance. 
In this research study the behavioral outcomes is considered as dependent variable $\mathrm{Y}$ and HR practices bundle as independent variable as HRP. The regression equation has been estimated as:

$$
\begin{aligned}
\mathrm{Y} & =\mathrm{a}+\mathrm{bHRP}+\mathrm{e} \\
& =31.917+0.253 \mathrm{HRP} \\
\mathrm{T} & =(18.352)(16.971) \\
\mathrm{P} & =(0.000)(0.000) \\
\mathrm{R} & =0.510, \mathrm{R}^{2}=0.371, \text { Adjusted } \mathrm{R}^{2}=0.370, \mathrm{~F}-\text { Value }=275.110 \\
\mathrm{P} & - \text { value for overall significance }=0.000
\end{aligned}
$$

The $\mathrm{R}^{2}$ is 0.370 . It means that only $37.0 \%$ of the total variation is explained by this model and other part of explanation is made by other variables which are not included in this study. The F-value is 275.110 and overall $\mathrm{p}$-value is 0.000 . Thus, the multiple regression model used in this study is fit and appropriate because ANOVA table shows that the F- value is significant at $5 \%$ level of significant.

The calculated $\mathrm{p}$-value for the variable HR practices bundle is 0.000 which is significant at $5 \%$ level of significance. So, HR practices bundle is significant predictor of behavioiural outcomes and its sensitivity index presented by regression model as beta coefficient is 0.541 . So, it can be conclude that this variable has significant and strong effect on the behavioral outcomes of the banking sectors of Nepal.

\section{Summary of the Study}

In study multiple regression model is used to know the effect of HR practices on behaviour outcomes of organizational performance where the $\mathrm{R}^{2}$ is 0.371 , it means that only $37.1 \%$ of the total variation is explained by this model and other part of explanation is made by other variables which are not included in this study. The Fvalue is 57.110 and overall $p$-value is 0.000 . While analyzing the beta coefficient, single variable job design's sensitivity to organizational performance is high followed by employee participation and compensation system. But all other variables recruitment and selection training and development, and career planning have also positive impact on behaviour outcomes of organizational performance. However, recruitment and selection, training and development, and career planning have minimum impact on behaviour outcomes of organizational performance. Thus these three HR practices are not much significant predictor of organizational performance as compare to other variables. 
In conclusion research found that all the HR practices variables consisting of recruitment and selection, training and development, performance appraisal, career planning, compensation system, employee participation, and job designs have positive impact on behaviour outcomes of organizational performance all the organization. However, job design, employee participation and compensation system variables have significant impact on behaviour outcomes of organizational performance in terms of employee motivation, employee cooperation, employee involvement and organizational citizenship behaviour whereas recruitment and selection, training and development, and career planning, have minimum impact on behaviour outcomes of organizational performance.

The primary purpose of this study was to evaluate the impact of best HR practices on behavior outcomes of organizational performance identified by Pfeffer (1994) and Guest, 2002). Based on Guest (2002), researcher hypothesizes that the following practices are related to organizational performance: Recruitment and selection, training and development, performance appraisal, career planning, compensation system, employee participation, job design. Regression coefficients of recruitment and selection, training and development, shows that system based Recruitment and selection, training and development, performance appraisal, career planning, compensation system, employee participation, job design positively contribute to organizational performance explained by employee motivation, employee cooperation, employee involvement and citizenship behaviour in nominal degree. This may mean that Nepalese banking institutions try to identify competent candidates to get into the organization. It means that if Nepalese banking sector invests a significant amount in selecting right people, they can improve employee motivation, employee cooperation, and employee involvement and employee organizational citizenship. This finding is consistent with the findings of Guest (1997) and Huselid (1995).

\section{References}

Adhikari, D. R. (2005). Human Resource Management, Buddha Academic Enterprises, Kathmandu, Nepal

Barney, J. (1991). Firm resources and sustained competitive advantage, Journal of Management, 17, 99-129.

Bhattrai, M. (2008). Organization of HR functions in Nepalese banks. An unpublished M. Phil. thesis, Tribhuvan University. 
Boxall, P. (1996). The Strategic HRM Debate and the Resource-Based View of the Firm. Human Resource Management Journal, 6, 59-75.

Brown, P.B. (2005). The eving role of strategic management development, Journal of Management Development, 24, 209-222.

Chand, S., Delaney, J. T., \& Huselid, M. A. (1996). The impact of human resource management practices on perceptions of organizational performance. Academy of Management Journal, 39, 949-69.

Datta, D. K., Guthrie, J. P., \& Wright, P. M. (2005). Human resource management and labor productivity: Does industry matter? Academy of Management Journal, 48, 135-145.

Dessler, G., \& Varkkey, B. (2009). Human resource management (1 $1^{\text {th }}$ eds). New Delhi, Pearson Publication.

Gautam, D.K. (2008). Strategic HRM in Nepal. Unpublished Ph.D. thesis, Kathmandu: Tribhuvan University.

Gerhart, B. (2005). Human resources and business performance: Findings, unanswered questions, and an alternative approach. Management Review, 16, 174-185.

Guest, D. (2000). Human Resource Management, employee well-being and organizational performance Paper presented at the CIPD Professional Standards Conference, 11 July.

Guest, D. (2002). Human Resource Management, Corporate Performance and Employee wellbeing: Building the worker into HRM. The Journal of Industrial Relations, 44 (3), 335-358.

Guest, D.E. (1997). Human resource management and performance: a review and research agenda. international Journal of Human Resource Management, 8, 263-276.

Harel, G. H., \& Tzafrir, S. S. (1999). The Effect of Human Resource Management Practices on the Perceptions of Organizational and Market Performance of the Firm, Human Resource Management, 38, 85-200.

Hersey, P., \& Blanchard, K. H. (1993). Leadership Style: Attitudes and Behaviors, Prentice Hall, Englewood Cliffs, NJ.

Huselid, M., (1995). Methodological issues in cross-sectional research and panel estimates of the human resource - performance link, Industrial Relations, 35, 400-422.

Kelley, \& Maryellen (1996). Participative Bureaucracy and Productivity in the Machined Products Sector. Industrial Relations 35, 374-399. 
Impact of Human Resource Management Practices on Behavioural Outcomes of Financial Institutions of Nepal : Pradhan I

Lawler, III, E. E. (2005). From human resource management to organizational effectiveness. Human Resource Management, 44 (2), 165-169.

MacDuffie, J. P. (1995). Human resource bundles and manufacturing performance: Organizational logic and flexible production systems in the world auto industry. Industrial and Labour Relations Review, 48, 197-221.

Ojha, S. K. (1996). Human resource management in skill development institutions of Nepal. An Unpublished Ph.D. Thesis, Kathmandu: Tribhuvan University.

Pant, P. R. (1982). Management of industrial relations in Nepal, The Nepalese Management Review, 2 (1), 37-45.

Pant, P. R. (1983). Industrial relation in Nepal: A comparative study of public and private undertaking in the jute industry, India: Department of Public Administration, Punjab University.

Pfeffer, J. (1994). Competitive advantage through people: Unleashing the power of the workforce. Boston: Harvard University Press research agenda'. International Journal of Human Resource Management, 8, 263-276.

Poudel, S. P. (2009). Effectiveness of HR functions in Nepalese commercial banks. An unpublished M. Phil. thesis, Kathmandu: Tribhuvan University. practices, Selection and Development Review, 13, 3-8.

Pradhan, G. (1997). Management development in manufacturing public enterprises in Nepal. An Unpublished Ph.D. Thesis, Kathmandu: Tribhuvan University.

Richardson, R., \& Thompson, M. (1999). The Impact of People Management Practices on Business Performance: A Literature Review London: CIPD

Storey, J. (1995). Managing Human Resources: Preparing for the 21st Century. New Delhi: Beacon Books.

Ulrich, D. (1997). Measuring human resources: An overview of practice and a prescription for results, Human Resource Management 36 (3),303-20.

Wright, P. M., McMahon, G. C., Snell, S. A., \& Gerhart, B. (1997). Strategic human resource management: building human capital and operational capability, Technical report, Cornell University, Ithaca, NY. 